\title{
Efforts to Get a Polish Priest for the Pastoral Work in Moravia (1927-1931) in the Light of August Hlond's (the Primate of Poland) Correspondence
}

Piotr Gołdyn / e-mail: piotr.goldyn@amu.edu.pl

Pedagogical and Artistic Department, University Adam Mickiewicz, Poznań, Poland.

Gołdyn, P. (2018). Efforts to Get a Polish Priest for the Pastoral Work in Moravia (1927-1931) in the Light of August Hlond's (the Primate of Poland) Correspondence. Czech-Polish Historical and Pedagogical Journal, 10/2, 56-64.

https://doi.org/10.5817/cphpj-2018-014

At the Archdiocesean Archive in Gniezno, in the Archive of the primate of Poland a correspondence was preserved. It was a correspondence between him, his office and other various entities - the Consulate of Poland in Ostrava, the Ministry of Foreign Affairs, Motherland School for Cieszyn Silesia and the others that were seeking a Polish priest for Moravia Poles asked the primate for the priest who not only celebrated services, granted sacraments, but also taught Polish children religion and cared about the national identity of Poles in Czechoslovakia. This correspondence became a base of dissertations qouted in this article.

Key words: pastoral work; primate of Poland; correspondence; Poland; Czechoslovakia

In the relation to settling the borders of Poland after the World War I a lot of Poles appeared in territorial areas of the other countries. It was caused to a certain extent by the migration which had still taken place in the times of annexation of Poland. The Great Polish Diaspora was in this territory of Czechoslovakia then. At the end of the 1920s it had no pastoral care and via the help of Motherland School (MS) in Cieszyn tried to recruit the Polish priest for the service in Ostrava. The course of these efforts can be seen in the correspondence kept in the resources of Archdiocesean Archive in Gniezno. It was the correspondence carried between the primate and all sorts of entities who were interested and involved in this action.

According to the correspondence still kept there it is known that they started in 1927. Then the primate's office received the letter sent by MS with the request for the priest for the service amongst Poles on Moravia. It contained the following text: "The number of the Polish clergy in the territory of Czechoslovakia has already been limited and supporting the religious education on this basis is almost impossible, and because of the lack of the Polish priest at Polish schools Czech priests are giving the religious education in the Czech language." Macierz recognized the inconvenience of that situation, so they dared to ask the primate to choose the Polish priest "for whom the Polish people in Moravia will be very 
grateful". ${ }^{1}$ A few days later Poznan Curia asked MS for the following issues: where, it means in which city (village) the priest would be supposed to arrive, what his means of money support would be and whether the authorities of the state and church would have nothing against the fact that the Polish priest would be working in Czechoslovakia. ${ }^{2}$

The primate received the answer to these questions very quickly. So the priest was supposed to settle down in Moravská Ostrava and he was supported by MS in Czechoslovakia. He was supposed to receive the salary equal to which the teacher of the departmental school usually received. If it comes to the authorities' agreement MS was convinced that such an agreement would certainly exist as the similar situation had already happened before. Apart from that MS Management Board was supposed to provide more specific information. Priest Józef Londzin signed the letter. ${ }^{3}$

The Management Board confirmed that the priest would be supposed to live in Moravská Ostrava and to teach at schools belonging to MS. For the first three years of the service his salary was supposed to reach 11,100 crowns plus 3,000 crowns as the bonus from MS. With every next two-year or three-year period of time it was supposed to be growing in such a way that between 16th and 18th year of work it was supposed to reach 21,000 crowns plus 3,000 crowns of the bonus. Of course, the working period of time in Poland would have been taken into consideration while fixing the salary. The Management Board also wrote that "the church authorities and especially the priest dean in Moravská Ostrava will willingly agree to include the religion education at Polish schools as the subject taught by the Polish priest and the simple reason for such a decision was the general lack of Catholic priests in Czechoslovakia and exactly that was the reason why teaching religion by Czech priests in Polish schools was impossible". It was also claimed that Polish government would not have anything against that decision. One more time the Management Board kindly asked the primate to grant this request. ${ }^{4}$

The primate promised that he would grant this request and will choose the priest to work in Czechoslovakia, but he said it would be possible only with the beginning of the next school year. MS Management Board was also asked to remain about the matter again in the following June. ${ }^{5}$

In June the Main Board of MS referring to the primate's request returned to the problem of choosing the Polish priest teacher to work in Czechoslovakia. They

1 Archdiocesan Archives in Gniezno, Archive of the Primate of Poland III, Czechoslovakia. Polish Schools, ref. 56, Letter from the MS of the Duchy of Cieszyn to the Primate. English, January 12, 1927, (hereinafter: AAG, APP III, CSP).

2 Ibidem.

3 AAG, APP III, CSP, Letter from January 22, 1927 to the Archbishop's Curia in Poznań.

4 Ibidem, Letter from the Main Board of January 26, 1927, b. p.

5 Ibidem. 
wrote then: "Taking into account our request means that the assignment to Moravia one of the brave priests - religion teachers will not only contribute to raise the level of the religious education at Polish schools in Moravia, but it will also be a great contribution to the national matter". As it turned out, the matter was more complicated than it seemed to be at the beginning so, in response the primate asked for postponing the issue for one year, on account of the necessity to contact the Olomouc archbishop. As it was a very delicate matter Cardinal Hlond wanted to talk personally to the Moravian church dignitary about it but there was some time needed to do that. ${ }^{7}$ However, Macierz Szkolna and particularly its Main Management Board did not stop the attempts to recruit the priest. On August 19, 1927 the next request was sent as there was no answer for the document from June 30, 1927.8

The matter was so important, that the Ministry of Foreign Affairs also got involved into it. Peculiarly when the consulate of Poland in Czechoslovakia turned to it. Then the consulate supported Macierz Szkolna in the action concerning the matter. In the letter to the primate, the consul - Karol Ripa - wrote: "The Polish people living in Moravia in the amount of over 10 thousand but gathered mainly in the Ostrava basin for over one and a half year have been deprived of the Polish priest's care and about 500 Polish school children have not been taught religious education for two years already. Also, the lack of a Polish priest creates a dangerous situation in Moravská Ostrava when separate Polish services in the parish church cannot exist. Such services had taken place every Sunday so far and Polish people willingly and in large numbers attended them. For the necessity of satisfying spiritual needs of the local Polish population and also the national consideration a Polish priest in Moravská Ostrava is really needed and his longer absence will cause the serious damage to the catholic and Polish matter in Moravia. ${ }^{9}$ It is necessary to admit that the consul used valid arguments in this letter and in the blunt way defined the situation. It is possible to get an impression that he even suggested that if there was the denationalization of Polish population in Moravia, the responsibility would fall on the primate.

In spite of the efforts taken by the primate and others they did not manage to recruit the priest for the school year 1927/28. So the efforts continued also in the next year. There is a letter confirming these efforts from July 1928 asking for the Polish priest to Ostrava. ${ }^{10}$ As the attachment to this letter there was the report of

6 AAG, APP III, CSP, Letter ZG MS from June 1927 to Office of the Primate of Poland in Poznań, b. p.

7 Ibidem.

8 AAG, APP III, CSP, Letter from August 191927 ZG to Office of the Primate of Poland, b. p.

9 Ibidem, Consul's Letter RP in Moravská Ostrava from 21. 10. 1927 Office of the Primate of Poland b. p.

10 Ibidem, The letter to the Prime of Poland dd July 25 1928, b. p. 
the consul of the Republic of Poland in Moravska Ostrava (unfortunately not dated), where it is possible to read: "In Moravia the urgent matter is assigning the Polish priest to Moravská Ostrava with the purpose to perform the pastoral and teaching function there. Since all these efforts are connected with the matter of lacking the secular priests in very Poland, therefore 'on account of the urgency, it is necessary to find at least a monastic priest and such a solution is accepted by Czech authorities"'11

Once again in August 1928, MS turned to the primate of Poland with the request to send the Polish priest to the work amongst the Poles in Moravia. Reading this letter we can find some regret concerning the fact that the matter had not been solved successfully for two years. Some other important arguments appeared concerning the fact that the Polish priest is absolutely needed. The Management Board claimed that the children listening to religious instructions in the Czech language are exposed to foreign pressure concerning the Polish cases and it can even be harmful. It can result in the situation that "the local Polish population is slowly dying not only for the Polish national identity, but also for the Church".12

The primate announced that he had undertaken some steps and gave the proposal that the work in Czechoslovakia would be performed by priest Jerzy Antecki, who was the priest in the Mohylow diocese, but the local bishop did not accept that decision. So, the search for a priest who could and wanted to go to Czechoslovakia and give the pastoral ministry there still were in progress ${ }^{13}$.

In December 1928 a hope like "the light at the end of the tunnel" appeared. The priest Biłko sent the letter to the Primate through his chaplain, in which he reminded, that during Hlond's trip to Rome and his staying in Bogumien the matter concerning the priest Polaczek had appeared again. This clergyman came from Cieszyń, Silesia, but he worked pastorally in the area of the Lwów archdiocese. He wanted to come back into his homeland so he was ready to provide Poles with the service in Moravia. Priest Biłko also reminded that the primate had agreed with such a solution (it was described in a detailed way by Bishop Gawlina who was travelling with Hlond). Priest Biłko, who was a friend of priest Polaczek, asked Hlond when it would be possible to establish priest Polaczek in the parish in Moravská Ostrava. Hlond, indeed, could not see many obstacles. The only obstacle was the lack of the Lwów archbishop's acceptance. The reason was that he could not influence the local hierarch's decision personally. He could also see that the Lwów archdiocese was suffering from the "disastrous" lack of

11 Ibidem, Excerpt from the Report of the Consulate of the Republic of Poland in Mor. Ostrava (undated), b. p.

12 Ibidem, Letter of the Main Board of MS dd August 17, 1928 to the Office of the Primate of Poland in Poznań, b. p.

13 Ibidem, The Letter of the Primate of Poland to MS in Cieszyn dd September 15, 1928, b. p. 
clergymen. However, the final resolution was left to priest Polaczek's decision. And if he got the permission for the exclusion of the priest from the bishop's authority to the Katowice diocese, he would not oppose to it. ${ }^{14}$

The Polish Consulate in Czechoslovakia also liked this proposal. Therefore, he made some efforts to convince the primate that priest Józef Polaczek should be a clergyman in Moravská Ostrava. Also the meeting in Bohumín was mentioned and recalled and a figure of the potential priest for Poles in Moravia was reminded to Hlond. Priest Polaczek was 36 years old then and he was a priest of the Lwów archdiocese (the fact was mentioned above) and he worked as the religion instruction teacher in Buczacz. The consul decided, that "he would be a suitable candidate to the vacant position" ${ }^{15}$ The Ministry of Foreign Affairs took a similar stand in this case. In the letter to Cardinal Hlond Wacław Gawroński, the head of the Ministry Department wrote: “(...) Priest Polaczek comes from Cieszyn and according to the consulate's opinion he is the most suitable candidate as he knows the local territory very well, not to mention the fact that he also knows absolutely the character of the population. (...) the Ministry hope, that this way Cieszyn inhabitants will receive not only the good priest but also the supporting power for the consulate in Morawska Ostrawa in the field of sustaining the spirit of the Polish national identity in the local area." In his response, the primate emphasized that he could not see any contraindications concerning the matter with only one exception, which had already been mentioned by him earlier. It was the Lwów archbishop's agreement with priest Polaczek's exclusion from the bishop's authority. ${ }^{16}$

Priest Józef Polaczek managed to obtain his superior's consent to leave the Lwów archdiocese. In his letter to the primate from 2 July 1929 he wrote: "I am daring to submit the following request to Your Grace. Having got a longed for dismissal from the Lwów diocese I humbly ask Your Grace to be willing to support kindly my application submitted for the religion instruction teacher in Moravská Ostrava and assign me for this post. I come from Cieszyn, I know the local relationships and I will be close to my family. Yet in February of this year I submitted my application to the R. P. Consulate in Moravská Ostrava and also to Your Grace's Office having got the assurance, that upon my dismissal from the Lwów diocese this post will be given to me."17

Indeed priest Józef Polaczek was dismissed from the ministry in the Lwów diocese by the end of June (the consulate reported it on July) and sent to the Katowice diocese. Therefore the Ministry asked the primate to depute the priest to

14 Ibidem, Priest Biłko’s Letter to Priest Chaplain Mędlewski in Poznań, b. p.

15 Ibidem, The Letter of the Consulate of the Republic of Poland in Moravská Ostrava from January 4, 1929 to Primate Hlond, b. p.

16 Ibidem, The MSZ Letter from January 4, 1929 to Cardinal A. Hlond, b. p.

17 Ibidem, Priest Józef Polaczek's Letter to the Primate of Poland from July 2, 1929, b. p. 
the pastoral work in Moravská Ostrava ${ }^{18}$. Hlond accepted both priest Polaczek's and the Ministry and the Consulate's requests and set him up as a priest in Moravská Ostrava. Then he informed the ordinary of Olomouc about it. ${ }^{19}$

It would have seemed that the problem had already been solved, but suddenly the case took an unexpected turn. Priest Polaczek thought everything was over and after three days he refused to accept the ministry in Moravská Ostrava, claiming that he wanted to work only within the Katowice diocese. The Katowice bishop had no power either based on the Canon Law nor any other ways to push the priest to work in Moravia. However, he announced that priest Polaczek could suggest the person who would substitute him. ${ }^{20}$ For Hlond it was quite an embarrassing situation, because he had already become involved into the correspondence not only with the Olomouc Archbishop but also with the Ministry of Foreign Affairs. He wrote then: "Now I would feel very sorry if I had to inform those dioceses about priest Polaczek's decision, particularly that I had already not been able (for reasons independent of me) to keep the promise concerning sending Polish priests to Moravská Ostrava." He also asked the Katowice bishop for pushing the primate to influence the priest Polaczek's to change his decision and fulfill his pastoral ministry for at least one year. ${ }^{21}$ The consulate also pressed the primate to influence the final decision and order priest Polaczek to take the pastoral service in Moravská Ostrava The consul was keen on solving this problem by sending Polaczek to Moravská Ostrava because Polaczek came from this area and knew the local people and the local relationships. He asked priest Polaczek, who temporarily stayed in Tychy, to start his pastoral ministry in Moravia on September 1, 1929.22 The Katowice bishop informed Hlond that he had talked to priest Polaczek who categorically had refused to take the pastoral service in Moravská Ostrava. However, he claimed that he had the other candidate who could take over this pastoral ministry. The Katowice bishop also pointed the clergyman priest Maks Dunajski from the Chełmno diocese who was interested in the pastoral ministry in Moravská Ostrava, because he wanted eagerly to leave his diocese. ${ }^{23}$

As it was mentioned above, priest Polaczek insisted on his decision and resigned from the pastoral ministry in Moravská Ostrava. However he pointed the priest from the Lwów diocese - priest Franciszek Tustanowski who would be ready to be sent to Moravská Ostrava. This clergyman was said to have graduaded from Roman Gregorianum, and in the Lwów archdiocese was only accepted temporarily, without inclusion in the bishop's authority, so according to priest

18 Ibidem, The Foreign Ministry Letter from July 23, 1929 to Cardinal A. Hlond, b. p.

19 Ibidem, Priest Cardinal Hlond's Letter to the Archbishop of the Olomouc from August 14, 1929, b. p.

20 Ibidem, Silesia Bishop's Letter from August 19, 1929 to Cardinal Hlond, b. p.

21 Ibidem, Hlond's Letter from August 21, 1929 to Bishop in Katowice, b. p.

22 Ibidem, Letter of the Consulate in Moravská Ostrava from August 23, 1929 to Hlond, b. p.

Ibidem, Letter of Bishop Lisiecki from August 30, 1929 to Cardinal Hlond, b. p. 
Polaczek there would be no problems with leaving this diocese. Allegedly during the stay in Cieszyn he asked priest Józef for giving him this post. ${ }^{24}$ Hlond was interested in getting some information concerning priest Dunajski. For that purpose he turned to bishop Okuniewski with the question whether it was true that priest Dunajski, having his agreement, was searching the post in the other diocese and whether it was really true, he wanted to know if it would be possible for him to agree to take over the pastoral ministry in Ostrava. ${ }^{25}$ Bishop Okuniewski agreed to send priest Dunajski there. On the occasion of the letter to the primate he sent a little characteristic of him claiming: "He is an eager priest, being able to work very well. There he turned other priests against him when he too eagerly started penetrating the matters which are rather of a personal than church nature." ${ }^{26}$ Hlond thanked for the reply and announced that he would turn to Dunajski with a question about the pastoral ministry in Ostrava. ${ }^{27}$ Indeed he turned to Dunajski announcing that the Chełmno bishop is not against him leaving the diocese ${ }^{28}$ Priest Dunajski in his reply to Hlond's letter asked a number of questions in which there were some questions such as: whether the flat is provided, what salary would be, whether it was necessary for him to know Czech language, whether he would be able to take his old parents with him and also whether that prefecture would be permanent and whether the job at school would be of national or private status etc. ${ }^{29}$ The consulate wanted to dispel priest Dunajski's doubts and tried to answer his questions, so he wrote the letter to Hlond and informed him: "(...) the work of the future religion instruction teacher in the local area will be difficult, because he will have to not only teach the religion at four folk schools and a departmental one but also he will be obliged to organize services in a church for Polish emigrants. As for the financial conditions they still are not established, so in any case we should predict that the religion instruction teacher would be applied for the state job by Polish government and as being on holiday would perform his duties in Moravská Ostrava." So if priest Dunajski decided to do that, it would be necessary to turn to the Ministry of Religious Faith and Public Enlightenment with the request for payable leave for the entire period of his stay in Moravská Ostrava. ${ }^{30}$

Fundamentally everything went in good direction if it comes about priest Dunajski. He was in the permanent mail contact with the consulate in Ostrava. However, he could not take the final decision, because he did not know exactly "what everything is based on", especially if it concerns his financial situation in

24 Ibidem, Priest Polaczek's Letters from August 29, 1929 to Episcopal Curia in Katowice, b. p.

25 Ibidem, Hlond's Letter to Bishop Chełmiński from October 2, 1929, b. p.

26 Ibidem, Letter of Priest Bishop Okuniewski to Hlond from September 25, 1929, b. p.

27 Ibidem, Hlond's Letter to Bishop Okuniewski from October 7, 1929, b. p.

28 Ibidem, Hlond's Letter to Priest Dunajski from October 7, 1929, b. p.

29 Ibidem, Letter of Priest Dunajski to Hlond from September 10, 1929, b. p.

30 Ibidem, Letter of the Consulate from October 23, 1929 to Hlond, b. p. 
Ostrava. What is more, he asked for the passport free of charge and insurance from the education office, but this was not done. ${ }^{31}$ In this matter, Hlond intervened to the consulate in Ostrava which at the same time was waiting for the response from the Ministry of the Foreign Affairs. The answer did not appear until April 14. We can read in it: "(..) according to information obtained from the Ministry of Religious Faith and the Public Enlightenment, (...) there is some doubt concerning the question whether priest Dunajski is really suitable for such a responsible job as the prefect is. He has not shown any outstanding pedagogical and education abilities until now. Apart from that there are some doubts whether priest Dunajski will accept this nomination." Taking everything into account the ministry suggested considering the candidacy of priest Tustanowski and asked Hlond to contribute to his dismissal from the Lwów diocese. ${ }^{32}$

As a matter of fact, alongside with the matter of priest Dunajski, the consulate had already taken some steps to recruit priest Tustanowski to work in Ostrava. They turned to this clergyman asking whether he would be interested in taking the service in Moravia. Hlond was also asked to assist in dismissing this clergyman from the Lwów diocese. ${ }^{33}$ In his answer to the consulate's question priest Tustanowski wrote: "With the greatest of pleasure I agree to take the job of a religion instruction teacher in Moravská Ostrava. For that purpose I submitted an application to Metropolitan Curia of the Latin rite in Lwów for dismissing me from the diocese. If it is possible, I also ask to urge Lwów to hurry with my matter and as soon as I get an answer from Lwów, I will go to Moravská Ostrava straightaway." 34

For the request concerning the intervention associated with the priest's Tustanowski dismissal from the Lwów diocese Hlond declared that he would not take such an action because of the limited number of the clergymen in this diocese. He remarked at the same time that he had a candidate there and pointed priest Dunajski adding that the Chełmno bishop did not have any obstacles against leaving the diocese by this clergyman. ${ }^{35}$

When some doubts concerning priest Dunajski appeared, a proposal to recruit priest Tustanowski came back, the case in which Primate Hlond was also involved. Considering letters of the consul and the minister they turned to the Lwów archbishop asking him whether he would be willing to dismiss priest Tustanowski from his diocese and let him take the job of the prefect in Ostrava. ${ }^{36}$ In June 1930

31 Ibidem, Priest Dunajski's Letter to Hlond from January 1, 1930, b. p. 
the ministry asked about the priest Tustanowski's case. Hlond informed that according to the letter from the Lwów bishop this priest could be released, but not before July $1,1931 .{ }^{37}$ The ministry insisted on Hlond and pushed him to arranged earlier dismissal note for priest Tustanowski. ${ }^{38}$

In April 1931 the matter concerning the recruitment of the priest for the Poles in Mory still was not settled. The ministry announced that temporarily a Slovak clergyman speaking Polish quite well took care of pastoral work amongst Poles. That clergyman was priest Osionko. But still it was necessary to acquire Polish clergyman. ${ }^{39}$ On June 1, 1931 priest Mieczysław Szałkowski from Cieszyn applied to Cardinal Hlond for allowing him to take the ministry in Ostrava. He had already talked about that with Consul Jung, the deputy to the Parlament in Prague. He was ready to take this community of five thousand Polish people of Roman Catholic denomination. ${ }^{40}$ In May and June a new concept appeared. It concerned another priest - Zygmunt Kasprzak from the Łódź diocese. However, the authorities of this diocese were not able to judge whether he was suitable for a position of the prefect in Ostrava, because he had spent most of the time outside that diocese. ${ }^{41}$

The correspondence was cut off in the year of 1931. So it is not known what the effect of these efforts was. Was the recruitment of the clergyman for the work amongst Poles in Moravia successful? We should look for it in the alternative sources and so this study is a starting point for further research. Here there are still two issues to discuss. The first one - it is a question why Hlond did not arrange sending the Salesian priests there being himself the member of this religious congregation. Perhaps the reason was that he would have to send at least three clergymen to create monastic community there. The second one - it is the question whether these efforts and the ineffectiveness in these few years resulted in creating by him a new religious congregation called popularly christians ${ }^{42}$ (The Society of Christ Fathers for Poles Living Abroad) whose members were mainly Poles and their main charisma was the work amongst Polish people outside the country. The answers to these questions should already be the subject of deliberations in other articles.

37 Ibidem, Letter of Metropolitan Curia in Lwów to Hlond from May 28, 1930, b. p.

38 Ibidem, Letter of the Minister of Foreign Affairs from August 20, 1930, b. p.

39 Ibidem, Letter of the Minister of Foreign Affairs to Hlond from April 20, 1931, b. p.

40 Ibidem, Letter of Priest Mieczysław Szałkowski to Primate Hlond from June 1, 1931, b. p.

41 Ibidem, Letter of Diocesan Curia in Łódź to the Primate from June 8, 1931, b. p.

42 In Polish - chrystusowcy. 